\title{
Teaching NeuroImages: Intraspinal Gouty Tophus
}

Meng Si, MD, Menglin Cong, MD, Dandan Wang, BD, and Hecheng Ma, MD

Neurology ${ }^{\circledR}$ 2021;96:e159-e160. doi:10.1212/WNL.0000000000010761

Figure 1 Intraspinal Gouty Tophus
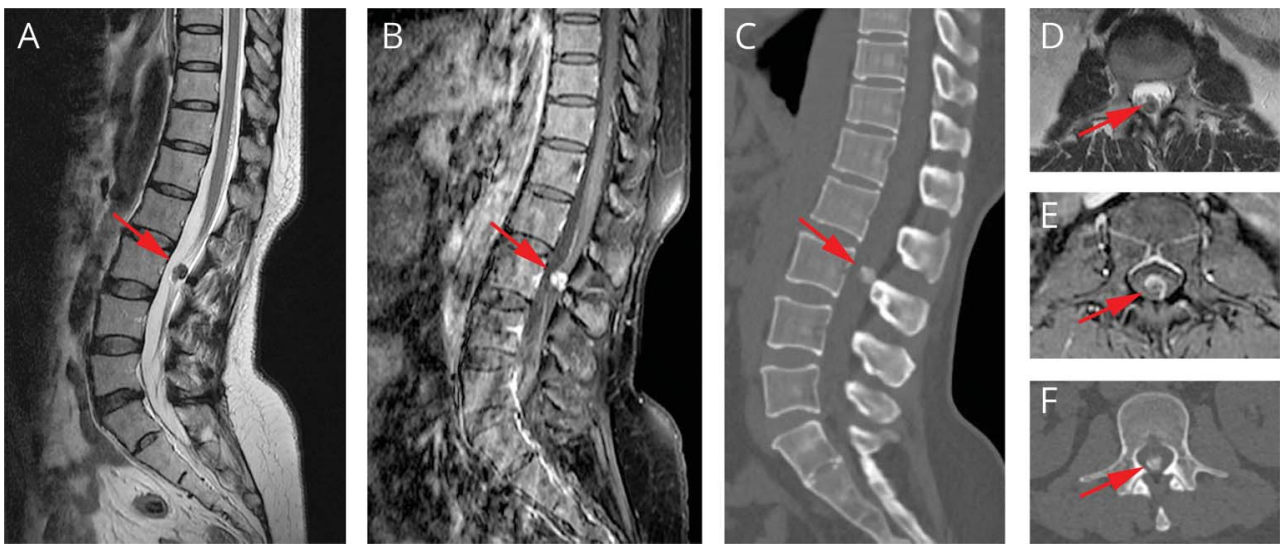

Magnetic resonance imaging ( $A$ and $D$, arrow) showed an intradural mass displacing the posterior spinal cord at the $L 3$ level, leading to lumbar stenosis. Contrast-enhanced MRI ( $B$ and $E$, arrow) showed obvious marginal enhancement. CT ( $C$ and $F$, arrow) showed the mass was calcified and the nerve root was compressed.

A 49-year-old woman presented to the orthopedic department with a chief complaint of severe low back pain for 2 years, with no neurologic deficiency on physical examination. Laboratory

Figure 2 The Pathology Slide

\section{Correspondence}

Dr. Ma

yopo2007@qq.com
MORE ONLINE

$\rightarrow$ Teaching slides

links.lww.com/WNL/ B208

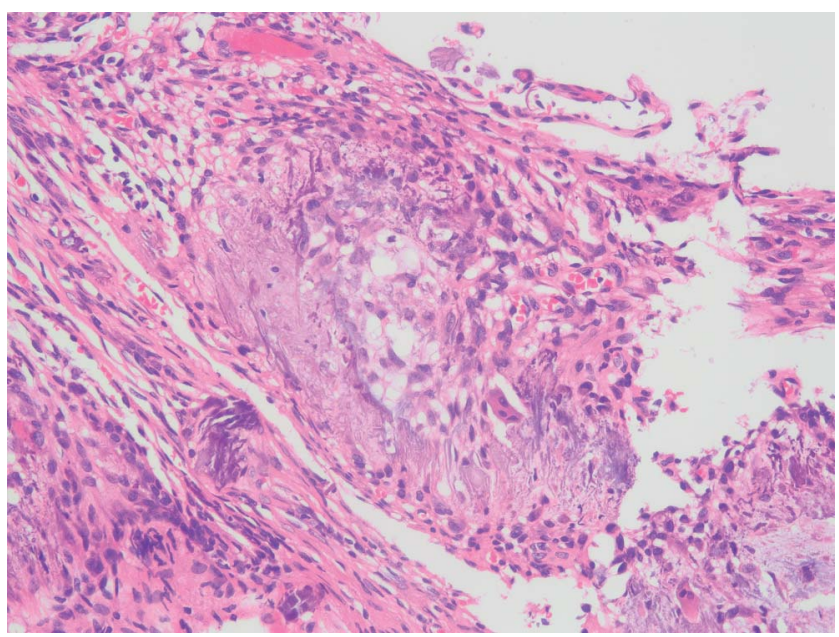

From the Department of Spine (M.S., M.C., H.M.), Qilu Hospital, Shandong University and the Jinan Center Hospital Affiliated to Shandong University (D.W.), Jinan, China. Go to Neurology.org/N for full disclosures. Funding information and disclosures deemed relevant by the authors, if any, are provided at the end of the article. 
investigations revealed no abnormities. MRI (Figure 1, A and D) showed an intradural mass displacing the posterior spinal cord at the L3 level, leading to lumbar stenosis. Contrastenhanced MRI (Figure 1, B and E) showed obvious marginal enhancement. CT (Figure 1, C and F) showed that the mass was calcified and the nerve root was compressed. The mass containing tophaceous deposits was removed surgically. As shown in the pathology slide (figure 2), the diagnosis was gouty tophus eventually, which is rarely presented in the spinal canal. ${ }^{1,2}$ The pain disappeared after the operation.

\section{Study Funding}

Study funding by the financial support from the National Natural Science Foundation of China (81902741), the Science Foundation of Shandong Province (project ZR2019BH077).

\section{Disclosure}

The authors report no disclosures relevant to the manuscript. Go to Neurology.org/N for full disclosures.

\section{Appendix Authors}

\begin{tabular}{lll}
\hline Name & Location & Contribution \\
\hline $\begin{array}{l}\text { Meng Si, } \\
\text { MD }\end{array}$ & $\begin{array}{l}\text { Qilu Hospital of Shandong } \\
\text { University, Shandong } \\
\text { University }\end{array}$ & $\begin{array}{l}\text { Acquisition of data, original } \\
\text { figure illustrations, draft of the } \\
\text { manuscript, and primary } \\
\text { clinical care of the patient }\end{array}$ \\
\hline $\begin{array}{l}\text { Menglin } \\
\text { Cong, }\end{array}$ & $\begin{array}{l}\text { Qilu Hospital of Shandong } \\
\text { MD }\end{array}$ & $\begin{array}{l}\text { Acquisition of data, reviewed } \\
\text { the clinical case, clinical care of } \\
\text { the patient, and revision of the } \\
\text { manuscript }\end{array}$ \\
\hline $\begin{array}{l}\text { Dandan } \\
\text { Wang, }\end{array}$ & $\begin{array}{l}\text { Jinan Center Hospital } \\
\text { BD }\end{array}$ & $\begin{array}{l}\text { Aniliated to Shandong } \\
\text { Anity, Shandong } \\
\text { the clinical case, and clinical } \\
\text { care of the patient }\end{array}$ \\
\hline $\begin{array}{l}\text { Hecheng } \\
\text { Ma, MD }\end{array}$ & $\begin{array}{l}\text { Qilu Hospital of Shandong } \\
\text { University, Shandong }\end{array}$ & $\begin{array}{l}\text { Clinical care of the patient and } \\
\text { revised and approved the } \\
\text { manuscript for intellectual }\end{array}$ \\
& University & content \\
\hline
\end{tabular}

\section{References}

1. Blasco JLS, Sarro NV, Marnov A, Martin JJA. Cervical cord compression due to intradiscal gouty tophus: brief report. Spine 2012;37: E1534-E1536.

2. Hasturk AE, Basmaci M, Canbay S, Vural C, Erten F. Spinal gout tophus: a very rare cause of radiculopathy. Eur Spine J 2012;21: 400-403. 


\section{Neurology}

Teaching NeuroImages: Intraspinal Gouty Tophus

Meng Si, Menglin Cong, Dandan Wang, et al.

Neurology 2021;96; e159-e160 Published Online before print September 4, 2020

DOI 10.1212/WNL.0000000000010761

This information is current as of September 4, 2020

Updated Information \&

Services

References

Subspecialty Collections

Permissions \& Licensing

Reprints including high resolution figures, can be found at: http://n.neurology.org/content/96/1/e159.full

This article cites 2 articles, 0 of which you can access for free at: http://n.neurology.org/content/96/1/e159.full\#ref-list-1

This article, along with others on similar topics, appears in the following collection(s):

Neuropathic pain

http://n.neurology.org/cgi/collection/neuropathic_pain Spinal cord tumor

http://n.neurology.org/cgi/collection/spinal_cord_tumor

Information about reproducing this article in parts (figures,tables) or in its entirety can be found online at:

http://www.neurology.org/about/about_the_journal\#permissions

Information about ordering reprints can be found online:

http://n.neurology.org/subscribers/advertise

Neurology ${ }^{\circledR}$ is the official journal of the American Academy of Neurology. Published continuously since 1951, it is now a weekly with 48 issues per year. Copyright () 2020 American Academy of Neurology. All rights reserved. Print ISSN: 0028-3878. Online ISSN: 1526-632X.

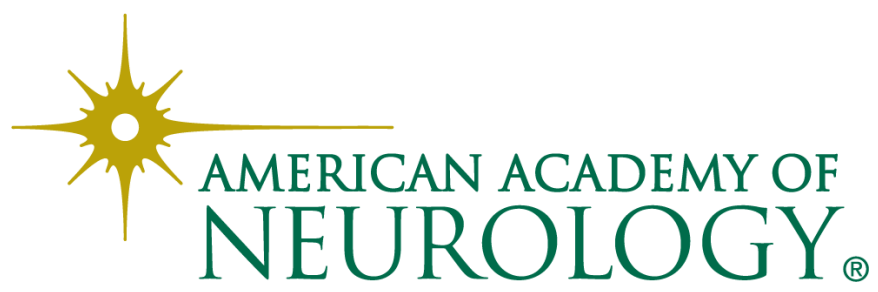

